środowiska protestanckiego - a zatem nie zabrakło i akcentu ekumenicznego. Jest to miasto Alberta Schweitzera, o który został również wygłoszony ciekawy referat biograficzny: Schweitzer w Strasburgu. Znalazł się czas na wysłuchanie specjalnego koncertu na organach Silbermanna, na których grał sam Mozart podczas swojego pobytu w Strasburgu. Do znaczących akcentów strasburskiego spotkania należała wizyta u biskupa miasta, abpa C. A. Branda, który w swej rezydencji czekał na spóźniających się gości, a następnie ich rewizytowal przewodnicząc końcowej koncelebracji eucharystycznej.

Spotkanie egzegetów w Strasburgu oprócz swoich korzyści naukowych miało również znaczenie symbolu. W dążeniu do zjednoczonej Europy ważną rzeczą jest stworzenie świadomości europejskiej universalitatis, czyli tego całego systemu wartości, które są dlatego europejskie, że są i biblijne, i chrześcijańskie. Bibliści mają ważne zadanie, które dokument Papieskiej Komisji Biblijnej o interpretacji Biblii w Kościele określa jako aktualizację tekstu biblijnego. Dzięki takiej aktualizacji Biblia może ukazać w nowym świetle takie wartości, o których się dzisiaj powszechnie mówi, a zwłaszcza w Parlamencie Europejskim i Radzie Europy: prawa człowieka, obrona życia ludzkiego, ochrona przyrody i troska o powszechny pokój.

Kraków

KS. JERZY CHMIEL

\title{
VII SPOTKANIE STOWARZYSZENIA KOORDYNATORÓW KATOLICKICH SZKÓL EWANGELIZACJI (KRAKÓW 1995)
}

Wezwanie Jezusa Chrystusa do głoszenia Dobrej Nowiny jest szczególnie aktualne w obliczu zbliżającego się Jubileuszu 2000 lat od narodzin Zbawiciela. Znaczenie i praktyczna realizacja tego wyzwania były tematem konferencji, świadectw i dzielenia się uczestników kolejnego spotkania koordynatorów katolickich szkół ewangelizacji, które po raz pierwszy miało miejsce w Europie Wschodniej w dniach 3-7 maja $1995 \mathrm{r}$. w seminarium XX Zmartwychwstańców w Krakowie. Spotkanie zgromadziło 65 delegatów z 35 szkół i centrum ewangelizacyjnych z 17 krajów Europy.

Tematem pierwszego dnia były dwa ostatnie dokumenty Jana Pawła II: Tertio millennio i Evangelium vitae. O. Manuel Casanova, SI, dyrektor Biura Ewangelizacja 2000 w Rzymie, przedstawił list apostolski papieża, który wyznacza drogę przygotowania Jubileuszu Roku 2000. Celem pierwszej fazy przygotowań (lata 1994-96) będzie głębsze uświadomienie chrześcijanom wartości i znaczenia Jubileuszu Roku 2000, który jako czas łaski ma być modlitwą uwielbienia i dziękczynienia za dar Wcielenia i Odkupienia dokonanego przez Syna Bożego. „Jubileusz powinien utwierdzić w dzisiejszych chrześcijanach wiarę w Boga, który objawił się w Chrystusie, umocnić nadzieję, wyrażającą się w oczekiwaniu na życie wieczne, ożywić miłość, czynnie służącą braciom" (Tertio millennio adveniente, 31). 
Faza druga przygotowań, od 1997 do 1999 roku, ma mieć charakter trynitarny. Tematem refleksji 1997 roku będzie: „Jezus Chrystus, jedyny Zbawiciel świata, wczoraj, dziś i na wieki" ( $\mathrm{Hbr} 13,8)$. Szczególnie w tym roku chrześcijanie winni powrócić do Biblii, ponownie odkryć Chrzest jako fundament życia chrześcijańskiego, odkryć katechezę jako „naukę Apostołów" oraz Maryje jako wzór wiary autentycznie przeżytej. Rok 1998 będzie poświęcony Duchowi Swiętemu, ponownemu odkryciu Jego obecności i działania w Kościele przez Bierzmowanie, charyzmaty i posługi. Zadaniem wierzących będzie odkrycie cnoty nadziei oraz wartości jedności wewnątrz Kościoła. Temat roku 1999: Bóg Ojciec pomoże okryć chrześcijanom pielgrzymowanie do domu Ojca, będzie wezwaniem do nawrócenia, okazaniem miłości, sprawiedliwości i pokoju, wyśpiewaniem Magnificat z Maryją, wybraną córką Ojca. Po konferencji o. M. Casanovy był czas na dzielenie się już podjętymi działaniami przygotowującymi Jubileusz.

Ks. Jim Birmingham przedstawił papieską encyklikę Evangelium vitae jako szczególne wezwanie i zadanie ewangelizatorów do obrony życia ludzkiego. Następnie Mario Capello z Centrum Ewangelizacyjnego na Malcie przedstawił projekt: Europe Arise. Będzie to seminarium praktycznej ewangelizacji dla młodzieży, zorganizowane w dniach 27-31 lipca $1995 \mathrm{r}$. w Brescii, we Włoszech, po którym przygotowane grupy wyjadą do różnych parafii w całej Europie, by przeprowadzić kursy, oazy i inne formy ewangelizacji młodzieży.

Drugi dzień poświęcony był tematowi ewangelizacji w Europie Srodkowo-Wschodniej. Złożyły się na niego głównie świadectwa i dzielenie się doświadczeniem ewangelizacji $w$ parafii i na ulicach, placach $i$ wyjazdach ewangelizacyjnych. Podkreślano ważność inkulturacji, dostosowanie metod i sposobów ewangelizacji do uwarunkowań religijnych i społecznych krajów postkomunistycznych. O. Daniel Ange OP mówił o swojej współpracy $\mathrm{w}$ ewangelizacji $\mathrm{z}$ prawosławnymi i grekokatolikami, podkreślając wspólne dziedzictwo świętych i męczenników oraz postawę miłości, która buduje jedność. Zacharie Faraq, Egipcjanin mieszkający w Genewie, mówił o ewangelizacji muzułmanów w Europie. Wielu z nich przyjmuje wiarę w Jezusa Chrystusa, lecz nie może jej otwarcie wyznawać ze względu na presję swojego środowiska. Muszą chodzić do meczetów, lecz tam modlą się nie do Allacha, ale do Chrystusa. Wspaniała ewangelizacja dokonuje się również przez świadectwa żon dyplomatów. Wszyscy mówcy podkreślali konieczność współpracy i wysiłku zespołowego, przestrzegając przed postawą izolacji jako jednym $\mathrm{z}$ największych niebezpieczeństw i wyzwań nowej ewangelizacji. Tego dnia Eucharystii przewodniczył ks. bp Jan Szkodoń, który w swoim słowie uwypuklił znaczenie wielości i różnorodności posług i charyzmatów $\mathrm{w}$ ewangelizacji.

W trzecim dniu rozważano ewangelizację $\mathrm{w}$ rodzinie i przez rodzinę. Swoje świadectwa złożyli: Marek i Dorota Maczuga, pracujący jako katecheci w jedynej parafii katolickiej w Tomsku na Syberii (Marek ukończył teologie na Papieskiej Akademii Teologicznej w Krakowie, a Dorota - psychologię na KUL-u); Vladimir i Katerina Izranov z Nowosybirska, którzy zostali zewangelizowani i ochrzczeni w $1992 \mathrm{r}$. a teraz ewangelizują w swoim środowisku (Vladimir jest docentem medycyny, a Katerina ukończyła konserwatorium muzyczne) oraz Tadeusz i Wanda Papuga z grupy Ruchu Swiatı-Życie w Krakowie. Podkreślili oni, że zaangażowanie rodziny $\mathrm{w}$ ewangelizacji winno mieć charakter długofalowy, a jej wyjazd misyjny może przybrać formę kilkutygodniowej pomocy profesjonalnej, np. medycznej, prawniczej czy organizacyjnej lub kilkuletniego pobytu na placówce misyjnej.

Stowarzyszenie Koordynatorów Katolickich Szkół Ewangelizacji ma charakter nieformalny, a jego spotkania zmierzają przede wszystkim do 
tworzenia ducha wspólnoty i współpracy pomiędzy istniejącymi przedsięwzięciami ewangelizacyjnymi. W takiej też atmosferze przebiegało spotkanie w Krakowie. Służyło budowaniu ducha braterstwa i jedności. Dodało wszystkim jego uczestnikom zachęty, wzbudziło nową gorliwość i zapał do podjęcia wyzwania roku dwutysięcznego, do budowania jeszcze bardziej chrześcijańskiego Trzeciego Tysiąclecia.

Kraków

MARIA KANTOR

\section{KOMUNIKAT TOWARZYSTWA BIBLIJNEGO W POLSCE}

Dnia 10 kwietnia 1995 roku odbyło się w Warszawie w siedzibie Towarzystwa Biblijnego pod przewodnictwem ks. Jerzego Banaka (Kościół Katolicki), Wiceprzewodniczącego Komitetu Krajowego Towarzystwa Biblijnego, inauguracyjne posiedzenie zwierzchników i przedstawicieli Kościołów: Kościoła Katolickiego, Polskiego Autokefalicznego Kościoła Prawosławnego, Kościoła Ewangelicko-Augsburskiego, Kościoła Ewangelicko-Reformowanego, Kościoła Ewangelicko-Metodystycznego, Kościoła Adwentystów Dnia Siódmego, Kościoła Zielonoświątkowego oraz Komitetu Krajowego Towarzystwa Biblijnego $\mathrm{w}$ Polsce, w celu przygotowania uroczystości Niedzieli Biblijnej oraz Ekumenicznych Dni Biblijnych w naszym kraju.

Uczestnicy spotkania powodowani pragnieniem upowszechnienia Pisma Swiętego wśród wiernych, zwrócili się do wszystkich Kościołów z zaproszeniem do udziału w Swięcie Niedzieli Biblijnej w dniu 14 maja b.r. i organizowanych Ekumenicznych Dniach Biblijnych pod hasłem: Pismo Swięte księga dla wszystkich ludzi.

W programie tegorocznych Dni Biblijnych przewidziane są nabożeństwa w świątyniach różnych Kościołów, wykłady o tematyce biblijnej, audycje radiowe oraz inne formy prezentacji Pisma Swiętego.

Praktyka wspólnych Dni Biblijnych ma zachęcić chrześcijan do stalego obcowania z Pismem Swiętym w Kościele, rodzinie i życiu codziennym. Nasze czytanie Biblii winno odbywać się $\mathrm{w}$ duchu ekumenicznym i prowadzić do pojednania i jedności wszystkich chrześcijan.

Zebrani przedstawiciele Kościołów wybrali Komitet Koordynacyjny, który skieruje do wiernych słowo $z$ okazji Niedzieli Biblijnej i czuwać będzie nad organizacją Ekumenicznych Dni Biblijnych w maju b.r. i w przyszłych latach.

Ponadto uprzejmie informujemy, że w sprawach dotycząccyh obchodów Ekumenicznych Tygodni Biblijnych i Niedzieli Biblijnej oraz spraw związanych $z$ działalnością Towarzystwa Biblijnego $w$ Polsce i na świecie chętnie służymy informacjami osobom zainteresowanym.

(Tekst nadestany do Redakcji przez Towarzystwo Biblijne w Polsce) 